\title{
SOCIAL (IN)JUSTICE, OR THE CONDITION OF GLOBAL CAPITALISM IN THE LOST CHILD (2015) BY CARYL PHILLIPS
}

\author{
MARTA FRĄTCZAK-DĄBROWSKA ${ }^{1}$
}

\begin{abstract}
The present article is a critical rereading of Caryl Phillips's latest novel The Lost Child (2015). It looks at the text as both a literary comment on the crisis of today's global capitalism and as an acute socio-economic analysis of the crisis' roots and effects. It is being argued that, by placing Wuthering Heights (1847) as an intertext for his contemporary novel and by linking the figure of Heathcliff with African slavery and contemporary poverty, Caryl Phillips aims to emphasise the affinity between the socio-economic conditioning of the nineteenth- and twentieth-century England, as well as between the contemporary and historical experience of economic marginalisation. Thus, he shows global capitalism as a universal experience of long modernity and asks some vital questions about its shape and its future. The following analysis, in line with recent scholarship in the field of postcolonial studies, combines postcolonial criticism with socioeconomic theories and argues that the novel deserves a place in the ongoing debates on the condition of the global economy, social (in)justice and (in)equality, which nowadays become part of the postcolonial literary scholarship.
\end{abstract}

Keywords: Postcolonial studies; social justice; global capitalism; long modernity.

In The Lost Child (2015), Caryl Phillips crosses spatial, temporal, and racial boundaries delving into intertextual dialogues with Wuthering Heights (1847). The Lost Child is a frame narrative which mixes a contemporary tale with excerpts from Emily Brontë's novel, as well as some meta-narrative investigations into the lives of the Brontës, all of which provide an interpretative framework for the text. The present article argues that Caryl Phillips's novel may be read as an acute literary comment on the (moral) condition of global

Assistant Professor, Department of British Literature and Literary Linguistics, Adam Mickiewicz University, Al. Niepodległości 4, 61-874 Poznań, Poland, e-mail: mfratczak@wa.amu.edu.pl. 
capitalism, which is gauged by the place the weakest occupy within the system. Building parallels between his contemporary and Brontë's classical text, Phillips shows that, despite the temporal distance that separates the two works, the reality of social, racial, and class inequality depicted in Wuthering Heights has changed less dramatically than one might have hoped. Hence, The Lost Child is not only an ambitious, intertextual endeavour, but also a multi-layered text with a clear didactic message conveyed through a vision of the world deprived of social solidarity and ridden with racial and class prejudice, in which poverty is stigmatised as a (moral) flaw.

The present article reads Caryl Phillips's novel as part of an emerging trend in postcolonial literary criticism, which connects postcolonial literary studies with the elements of social and economic theories and thus showcases postcolonial fictions as meaningful analyses of the metanarrative of global capitalism and its socio-economic conditioning. In fact, the connection between colonialism and global capitalism has always been recognised in postcolonial studies; many scholars have investigated the relationship between economic dispossession of the Other and the profit gaining policies of the metropolis. Edward Said, for example, famously taught us that imperialism was a "principally economic" movement that created discursive strategies and built power structures in order to secure resources necessary to maintain economic stability in the West (Said 1993: 5). This aspect of postcolonial critique has been somehow downplayed in recent years; however, as Melissa Kennedy writes in Narratives of Inequality: Postcolonial Literary Economics (2017), the 2008 economic crisis, which revealed deep structural inequalities in the Western metropolises, reminded us that the world economy is worryingly fragile, susceptible to speculation, and that the West is just as much exposed to the unfavourable effects of global capitalism as the rest of the world. As a result, postcolonial literatures, and their insights into global capitalism, have started to be revisited more broadly as not only fictional records of the human experience, but also as valuable sources of knowledge about global capitalism as a system. ${ }^{2}$ Nowadays, Kennedy (2017: 21) adds, "literature matters [not only] to writers, readers, and critics [but also] to many social scientists, including economists, who cite fiction in their scholarship". Such a change has a significant impact on postcolonial literary criticism, too. As social scientists are no longer wary of resorting to literature, literary scholars no longer shun reading literature through the prism of socioeconomic studies. ${ }^{3}$ This, in turn, necessitates forging a new language that would

2 In her book, Melissa Kennedy focuses inter alia on Amitav Ghosh's Ibis trilogy (2008-2015), which revolves around the history of opium trade and links personal narratives with insightful analyses of world economy and capitalism.

3 A similar line of thinking about postcolonial fiction and global economy may be found in Uncommon Wealths in Postcolonial Fiction (2017) - a collection of essays by such famous 
reconnect the impersonal discourse of political economy with the highly personal language of literature (Kennedy 2017: 22). As such literary investigations are of great conceptual, social, and political value today, they may well open with critical (re)readings of Caryl Phillips's fiction, which has always been invested in political and socio-economic themes and thus remains a perfect subject for such analyses.

Caryl Phillips is known for being a versatile writer who keeps returning to the English canon in his works and integrating the elements of various genres, from literary texts to music, creating kaleidoscopic, "counterdiscursive" literature (Ledent 1996: 301-302). Phillips's use of intertextuality, of which The Lost Child is a good example, stems not only from the wish to artistically enrich his fiction but also from Phillips's undying belief in "the power of literature to provide, as well as deny, a sense of identity" (Buonnano 2017: 95). More often than not, Caryl Phillips gives the voice back to those marginalised in mainstream cultural narratives, and thus symbolically provides them with the sense of belonging and cultural identity. This trend in Phillips's writing is most often associated with his fictional reconstructions of the African diasporic experience, especially in the context of their transcontinental migrations and their symbolic and material disposession (cf. Gilroy 1993: 10). Nonetheless, his main artistic ambition, as Bénédicte Ledent claims, has been to produce a body of works that confront and retell Western history (Ledent 1996: 300-308). In this alternative vision of the past, Phillips's main historical protagonists are the displaced, the homeless, and the persecuted (Nasta 2000: 64; Schatteman 2009: xiv). Reading Phillips's fiction, then, is a profound lesson in social and historical sensitivity. Not only does Phillips reclaim those once silenced by history, but also revisits the historical experience of his protagonists, which he sees not so much as part of the past but as part of the present. Thus, he undermines a clear temporal separation between the past and the present and reveals lasting socio-economic frameworks which combine the colonial and postcolonial world into a single narrative of (post)colonial capitalism. Ian Baucom (2005: 24) deems such a literary (re)vision of history "melancholic" and argues that:

[in the world where] the possibilities of progressive politics seem to be dominated by universalising end-of-history narratives, triumph-of-the-market rationalities, speculative epistemologies, and the twin ideals of consensual disinterestedness and liberal cosmopolitanism, the melancholy fact of history ... offer[s] the promise of

postcolonial scholars as Neil Lazarus and Helen Tiffin, for example, published by Brill. On the other hand, an interesting example of economists turning to literary and cultural narratives is Economics of Good and Evil (2011) by Tomáš Sedláček, where the author argues that economy is essentially a cultural narrative and that its rules are coded in stories told and retold through the centuries. 
an alternative vision, knowledge, and politics of the global, one which can predicate itself on a frank avowal of interestedness: in the subaltern, in the hautological, in the multitudinous scenes of global injustice, in an entire planetary array of melancholy facts, scenes, images, and fictions of history

(Baucom 2005: 226; italics in the original)

Therefore, Phillips's intertextual dialogues, with their European literary tradition and the history of capitalism exemplified in The Lost Child, may be seen as part of his life-long struggle to construct the alternative politics of the global by means of works of literature that invariably speak up for the weak and call for social justice.

Such a tendency is visible already in the first chapter of The Lost Child, where we meet an unnamed female protagonist, an African slave, who reminiscences about her past in the West Indies, her subsequent journey to England, and the (im)possible future of her son. She is acutely aware of the limited possibilities she has been offered in the world as an African slave and a female. From the very beginning, her position in society was defined by the desirability of her body, which was nothing more than a commodity on the market of male passions. In the West Indies she could not hope for much as she was considered too black and therefore unattractive (The Lost Child, 4). Her situation temporarily changed once she was transported to England where her exoticism was in demand. However, when she "found herself with child ... her circumstances declined [again]" (The Lost Child, 11), as from then on she depended solely on the goodwill of her child's father, for whom she was a "burdensome secret" (The Lost Child, 11). Despite such difficult circumstances, she has high hopes for her son who, now seven years old, is gently caring for his ailing mother. She believes he may go beyond the limitations imposed on him by the society and rebel against being a servant: "[s] he has seen the other [African] boys, ornately attired in silks ..., walking behind fair ladies. Her son will never walk behind a fair lady" (The Lost Child, 6). The introductory scene closes when the mother and the boy are separated; in the closing frame we learn that the boy is taken away by a man named Earnshaw and that he will grow up to become Heathcliff.

Thus Phillips creates a link between the African slavery and the famous social outcast of English fiction. As Giovanna Buonnano (2017: 98) argues, by liking Heathcliff's provenance with the African Other, Phillips shows Heathcliff as "the product of the triangular trade, of the mobility and traffic of colonial/imperial Britain, a literary figure that hides the uncomfortable truths of imperial history behind his exotic, dark-skinned gypsy looks". I believe, however, that one may divorce the story from the immediate context of the colonial transatlantic trade and read it as a more universal tale of socio-economic oppression which came into being with colonialism, but which lasts until today as part of the metanarrative of (global) capitalism. Within its realms, race and class come 
together, both marginalising and racialising certain social groups at the same time. This process has not been confined to the African slaves alone, but is used on the population of Ireland and Scotland who, at least in the English imperial discourse, also signified the racial and cultural Other (cf. Loomba 2005: 107). At one point in the history of the colonial endeavour, then, race and economic dispossession conflated, providing a fruitful breeding ground for racism; systemic theories of racial superiority evolved as tools to justify the necessary economic exploitation of the Other and, as such, they became inseparable from economic violence (Williams 1944: 34; Heuman 2014 [2006]: 15). Nowadays, racism and economic discrimination are still conflated and deeply rooted into the institutions of the Western world. Suffice it to say that, statistically speaking, African Americans are still significantly less affluent than white Americans. As The Washington Post informs "[i]n five-year American Community Survey data from 2009-2013, more than a third of all poor African Americans in metropolitan Chicago live in high-poverty census tracts", which means that "[it] has gotten worse since 2000", being "about 10 times higher than for poor whites" (Badger 2015).

One may argue, therefore, as Terry Eagleton (2005 [1975]: 104) once did, that the discrimination experienced by Heathcliff as a tone darker than the rest of the Earnshaw family is not so much a direct result of his race as a consequence of his social status as their inferior. One may recall, for example, the scene of Heathcliff's first introduction to the Earnshaw family where the connection is immediately drawn between the boy's physical condition as a "dirty, ragged, black-haired child" and his supposed "gipsy" origin (Wuthering Heights, 25; original spelling). Mr Earnshaw's decision to take him home is therefore motivated by his pity for the child's deplorable state. As Mrs Earnshaw does not fail to point out, however, it is also uncalled for, as her husband does not think about how they are going to "fend for" this new addition to their family (Wuthering Heights, 25). Throughout the novel, Heathcliff is not allowed to forget about his social inferiority; at one point, Catherine scorns him for being "black and cross" - the fact to which she became sensitive only "because [she got] used to Edgar and Isabella Linton" (Wuthering Heights, 37). Also Nelly's words describing Heathcliff's struggles with work and education may strike one as cruel. She says that:

[when Heathcliff] had reached the age of sixteen then ... he had by that time lost the benefit of his early education: continual hard work, begun soon and concluded late, had extinguished any curiosity he once possessed in pursuit of knowledge, and any love for books or learning. ... He struggled long to keep up an equality with Catherine in her studies, and yielded with poignant though silent regret: but he yielded completely ... [t] hen personal appearance sympathised with mental deterioration: he acquired a slouching gait and ignoble look; his naturally reserved 
disposition was exaggerated into an almost idiotic excess of unsociable moroseness; and he took a grim pleasure, apparently, in exciting the aversion rather than the esteem of his few acquaintances.

(Wuthering Heights, 47; italics mine)

Through these and similar examples one may see how the Earnshaws conviction of Heathcliff's moral and physical darkness conflates into a coherent narrative of his cultural and racial Otherness, where poverty, social class, presumed bad blood and lack of sophistication are being forcibly brought together only to become inseparable from the very idea of a typical Other.

Hence, there are many reasons why Phillips could have chosen Wuthering Heights as an intertext to his contemporary tale, one of them being the fact that it is a profound story about the impossible transgression of social norms in a privilege-based society, in which there is no freedom for both the social insiders and the social outcasts (Eagleton 2005 [1975]: 100). Catherine and Heathcliff's love "crystalises under the pressures of economic and cultural violence" and reveals that "the tragic truth that the passion and society [the novel] presents are not fundamentally reconcilable" (Eagleton 2005 [1975]: 104). The conflict between Heathcliff and Edgar Linton symbolises the clash of two social classes, the old gentry and the new capitalists, as Heathcliff quickly learns that power is inseparable from capital. Thus, he "amasses a certain amount of cultural capital in his two years' absence in order to shackle others more effectively" (Eagleton 2005 [1975]: 104) and in eyes of the characters of Wuthering Heights is even accused of excessive greed: "[h]e has nobody knows what money, and every year it increases. Yes, yes, he's rich enough to live in a finer house than this ... . It is strange people should be so greedy, when they are alone in the world!" (Wuthering Heights, 23). Putting it differently, Heathcliff first decides to play by the rules of the system so as to defeat it. Soon, however, he discovers that the promise of individual freedom offered by capitalism is a mere illusion. " $[\mathrm{H}]$ is rise to power symbolises at once the triumph of the oppressed over capitalism and the triumph of capitalism over the oppressed", as Eagleton (2005 [1975]: 112) explains, pointing out that ultimately Heathcliff loses his battle for setting his own rules. However, like many of Wuthering Height's fans, Eagleton considers Heathcliff an admirable figure. His boldness and strength of character do not fail to impress and his ultimate fall is as much a result of his flaws as it is of the social norms he encounters.

Caryl Phillips seems to be of a similar opinion as he invites his readers to recognise various dimensions of Heathcliff's experience in all the social outcasts depicted in his novel as they struggle with the limitations inscribed by capitalism and by the class structure of the contemporary society. For example, the experience of the titular lost child reverberates in the main protagonist of the 
novel, Monica Johnson, a woman born to a lower middle class family in Leeds. The readers follow Monica's adult life in the England of the sixties and seventies, but we also get a brief insight into her formative years. Monica's father is a teacher and he rules his family in a style of "benevolent patriarchal authority" (The Lost Child, 19). There is no emotional intimacy within the family and they live alongside each other like strangers (The Lost Child, 21). Thus Monica grows up a quiet, intelligent girl, but confused as to her own needs and passions. She knows she is expected to go to one of the red brick universities, but chooses to apply to Oxford instead. Her decision is highly unusual as she has no familial ties with the university and knows none of its former students, who could vouch for her (The Lost Child, 21). Surprisingly, she manages to get in, but this is only a beginning of her story. As one of few Northerners at Oxford, Monica feels lonely and gravitates towards other marginalised groups, for example foreign students on Commonwealth scholarships. Eventually, she embarks on a relationship with Julius Wilson, a decade older PhD candidate from the Caribbean (The Lost Child, 22). Soon, however, she is to discover that it is impossible to reconcile her previous life, her studies, and her married life. Monica's father is the first to express open disapproval of her marriage. He does not conceal the fact that her husband, being a poor scholar of Afro-Caribbean origin, does not meet his expectations of a son-in-law. Thus, he gives in to the stereotype of impossibleto-overcome racial difference and cuts off all ties with his only daughter, deeming her marriage as a waste of life and career. Moreover, at the university it is unanimously understood that, as a wife and a mother-to-be, Monica will be supporting Julius in developing his career, rather than pursuing her own. Therefore, nobody is surprised when she quits.

Lastly, and most disappointingly, Julius too expects her to abandon all her dreams. He is genuinely surprised when she starts raising objections as she "never agitated for more visibility in the relationship" (The Lost Child, 27). He does not see any contradiction in the fact that, as a man of colour himself facing economic and political discrimination in England (The Lost Child, 29), he too contributes to Monica's oppression. In a rare moment of self-reflection he notes that:

\footnotetext{
Monica had given him security and purpose as he struggled to finish his dissertation, but she had never really shown full appreciation for his reciprocal gift of marriage. For some reason, she seemed to have grown to resent him, and over the years she had made no effort to claim a role and had simply deposited herself as a burden at the centre of his life.
}

(The Lost Child, 49)

Monica, then, is seen by her man as a burden, much like the female slave from the beginning of the story. Moreover, much like Catherine from Wuthering Heights, she is trapped in an unhappy marriage, though she is at least able to make 
a decision to leave her husband. "I' $m$ tired, poor, and worried that because I don't know how to be myself", she tells her husband, "I don't know how to be a mother to these two boys, who deserve a damn sight more than we've been able to give them" (The Lost Child, 52). This will prove to be the only moment of rebellion on Monica's part, in which she tries to accentuate her identity as an independent individual, and not as a wife and a mother. Needless to say, Julius gladly embraces the opportunity of separation, which he treats as an excuse not to take any responsibility for his family. He never pays any money to support the children and Monica never hears from him again; thus, she is left on her own to face the consequences. At this point in the novel one would expect that, as a twentiethcentury woman, Monica will have more support from society than women in her situation have had before; however, with two boys, no job, no degree, and no family to support her Monica's situation is desperate.

Though Monica knows that her father sees her as tainted by association with Julius and thus he will never take her back, she decides to go back to Leeds and accept a position of a junior librarian (The Lost Child, 56). She is well aware, however, that without proper education she will not be able to get a better job and offer her sons a better future. Therefore Monica

finally work[s] up enough courage to contact the admissions office at her old
college, they wrote back and told her that she would be most welcome to return and
complete the final year of her degree, but only after she had 'established a domestic
situation that would be compatible with study.'

(The Lost Child, 67)

This well-phrased, but deeply cruel, reply is a heart-breaking moment for Monica, who realises that the university administration does not sympathise with her plea. In-between the lines, they blame her for having made a bad decision and judge her present living situation. By arguing that she has only herself to blame, they imply that all our choices are conscious and made in full awareness of their possible implications. In fact, our consumer, professional, and credit choices, result from conscious and unconscious factors and therefore contemporary economists turn towards psychology and sociology to better understand the process of decision-making. As one may read in Identity Economics (2010) by George Akerlof and Rachel Kranton, our family background, socialisation, and support we get from the group, all affect our life-changing decisions. Sometimes people make a choice that harms their long-term economic or educational prospects, because they believe that this behaviour is expected from them by the community or because they believe that it is a social norm. Moreover, experiments prove that "[p]eople behave differently when they are reminded, even subtly, of their racial, ethnic, and gender identities" (Akerlof \& Kranton 2010: 30) and thus the letter from the university is shockingly insensitive; not 
only does it remind Monica of her place in society as a divorced woman, but also undermines her self-confidence and solidifies her conviction that there is nothing she can do to better her fate.

Economically speaking, the letter reveals a lack of social solidarity on the part of the university and academic community. Risking some overs-implification, one may say that social solidarity is premised on a belief that being part of a certain community makes one responsible for the well-being of all the members of the said group; it is also a privilege, as one is entitled to certain rights and support from the group regardless of one's position in the social hierarchy. "Solidarity [can be] understood more clearly by considering some of its opposites. The experiences of social alienation, division, conflict, and defection show what the absence of solidarity looks like"; it "trades heavily on ... what people identify with, what they feel the same as (identical)", so it is possible only if the members of a given group are ready to sympathise with one another beyond the constraints of class, race, and gender (Smith \& Sorrell 2014: 238). Monica, then, is one of many characters shown in the novel who do not experience this sense of communal belonging and who are denied the protection of the group, being left to her own devices instead. At this moment in the novel it is clear that there are no ready-made solutions within the system that make it possible for a single mother to finish her degree, and there is no good-will on the university's side to make a potentially problematic situation easier. Thus Monica is left to fend for herself, but the socio-economic obstacles she is about to face will prove insurmountable. Though she has a job, she earns too little to cover the basic needs of herself and her boys. For example, "she couldn't afford to move out into private accommodation" (The Lost Child, 69), so she is relocated to community housing. To be fair, many pity her situation, but any help she is offered comes with the sense of even deeper humiliation. For instance, when after years of loneliness she finally meets a man and spends a romantic night with him, he "[leaves] money for her, which meant that either he'd got the wrong idea about her or he really cared, but ... she didn't know what to think" (The Lost Child, 92). Later on, when Monica becomes unable to support her two sons, she succumbs to depression and asks the state for part-time foster care. Though help is granted, it is made very clear to Monica and her boys that their situation is a result of Monica's improper, and probably immoral, conduct and laziness and that they all should be ashamed of their poverty. The belief that the poor "are lazy, work-shy and do not want to be educated and improve themselves, emerged in the late Middle Ages and persists in one form or another to this very day" (Jütte 1994: 158). Colonial discourse, too, used this rhetoric and described the natives as indolent, lazy, and incapable of taking proper care of themselves and thus requiring assistance (Said 1993: 167). Such an approach is unfair and hurtful in its own right, but the real problem lies in the fact that it is also institutionalised. 
Putting it differently, the poor who solicit help from the state are constantly reminded of their Otherness and are well aware that poverty is seen as a moral flaw. This, in turn, means that they adopt certain strategies to deal with it, some of which may be self-destructive by definition (Jütte 1994: 158). Poverty, then, is a vicious circle which cannot be easily broken.

Monica and her sons are the objects of such institutionalised contempt and moral stigmatisation. While in foster care, the boys are never allowed to forget that they are poor and, therefore, somehow deeply different. Their foster carer, Mrs. Swinson, does not hide the fact that she blames the boys and their mother for being poor, which for her is tantamount to a moral flaw. "During the war I even had evacuees - Cockneys from London - dirty beggars all of them", she tells the boys. Then she shames them for having old worn-out clothes: "I couldn't understand a word they were saying, but at least their mothers knew to send them with some proper clothes" (The Lost Child, 119). "I'll wager [your mother] can use her depression as an excuse, but those plucked eyebrows give her away" (The Lost Child, 119), she adds, linking Monica's moral conduct to her economic situation. When in public, however, Mrs. Swinson makes "a big show" of helping the boys "as though she wanted all and sundry to know that these boys were in her charge and she was going out of her way to provide them with a roof and bring them up to scratch" (The Lost Child, 120). Also, at school the boys are picked on due to many visible signs of their poverty but, most worryingly, their stigmatisation is inscribed into the schooling system itself. On his very first day, the younger of the two boys, Tommy, "[feels the] double humiliation of not having anybody to talk to and understanding that he will most likely have to ask somebody where the line is for those who have free school dinners" (The Lost Child, 118). Hence, poor children are spatially separated from average kids - a seemingly trivial incident, which may have potentially grave implications. Though mainstream economic theories describe an average student as a "rational decision maker who weighs the economic cost and benefits of staying in school" (Akerlof \& Kranton 2010: 62), such an approach is deeply flawed and needs to be fundamentally reconceptualised. Schools are institutions with "social goals" and, as such, their structure should not imitate the structure of the market, where every consumer is responsible for his or her choices. Schools "impart norms regarding who students should be and that they should become" (Akerlof \& Kranton 2010: 62), and thus the message Tommy gets from the school as an institution is deeply troubling. Not only does it strengthen his already deep sense of inferiority, but also makes him believe that stigmatisation is a social norm. Such examples of systemic inequality, as Danny Dorling argues, are based on certain beliefs and myths which have shaped capitalism and its institutions throughout the centuries. They include, for example, a belief that capitalism creates endless opportunities of social and economic progress, a conviction that 
economic failure stems from one's own character flaws, and that elitism and capital concentration benefit the whole society (Dorling 2015: 3). Despite the fact that we have had ample evidence that global capitalism has deepened economic inequalities across the world and spread the sense of economic insecurity among the middle classes (Bauman 2007: 32-34), these myths are still perpetuated within the mainstream debate.

On the other hand, "[s]imply saying that you reject the labels attached to these beliefs (elitism, exclusion, prejudice, greed and despair) is not sufficient to reduce injustice", as Dorling (2015:3) argues further, and Caryl Phillips's narrative seems to prove the same point. Namely, the most telling and troubling element of Tommy's story is the fact there is nobody in the novel who would try to protect the boy, even in a somehow hasty and misguided manner as Mr Earnshaw did try to protect Heathcliff in Wuthering Heights. Instead, the readers observe the process of the boy's gradual physical and mental decline; the new school, and the pressure of foster care, start taking their toll on Tommy. The boy shuts down, becomes very quiet and refuses to talk to his older brother, Ben, about his problems. Finally, he musters the courage to inform Ben that he does not want to be fostered and Monica makes her last effort to take care of her sons on her own. However, as Ben remembers, "things began to deteriorate after the fostering with Mrs. Swinson didn't take" (The Lost Child, 159). Once back at home, Tommy becomes even more distant and closed; Ben assumes that he is being bullied, but does not force Tommy to talk about the issues he does not want to share. Strangely enough, Tommy's only friend is his mother's boyfriend, Derek Evans. Things change for the worse yet again when, one day, Tommy disappears without a trace. Reminiscing about this part of his life, Ben admits that he has suspected that Derek had something to do with Tommy's disappearance. It was obvious that the man "was trying to impress our Tommy" by giving him little gifts; "my brother nearly always came back home with a small bottle of Lucozade, which Derek Evans claimed would give Tommy energy" (The Lost Child, 165), Ben remembers. Despite his suspicions, Ben, himself still a boy, is ill equipped to take over the role of an adult and confront Derek.

Tommy's disappearance marks the end of their nuclear family. At this point Monica completely disintegrates. She spends some time in mental health institutions and then dies in London in mysterious circumstances. Paradoxically, her long estranged father is the only person available to identify her body. "The whole thing was depressingly straightforward", he notes, "[t]hey'd closed Monica's eyes, but they'd not done anything else for her, so her makeup was all streaked, and he could see that she was thin as a rake. She looked emaciated" (The Lost Child, 199), he thinks, and his words strike a tone of both pity and accusation. Ben is luckier; he is taken away by the social services and once again placed in foster care. This time he is fostered by the family named the Gilpins, 
who have two girls of their own, both a bit younger than Ben. They treat him with suspicion as he is young and has a different skin colour, thus being a potential threat to the purity of their daughters. Despite the fact that they are unable to get rid of their racial prejudice, they are not cruel or dismissive, however, like Mrs. Swinson used to be. Ben spends four years in their house where he never feels at home. "[T] he whole family more or less ignored me" (The Lost Child, 183), he says, and dreams of getting away and studying at the university, which he knows can guarantee him a better future. Ben is determined to be successful, but his admirable determination is underpinned by guilt. He keeps being haunted by the memory of Tommy, blaming himself for what has happened to his brother:

I should have done more for Tommy, and that's what had been keeping me awake
for years now: the feeling that it was my fault. As a family we had nothing, so of
course it was straightforward enough for somebody to turn our Tommy's head. It's
easy to turn a kiddie's head when he has nothing. I'm sorry our Tommy.

(The Lost Child, 189)

Ben knows that the reason why Tommy was hurt, and why the police and the community were not interested in him as much as they should have, results from the fact that they were poor and powerless. Ben is sure that money and power are connected and determine one's place in the world. Since it is too late for his brother, he is bound to get both in his name.

A few years later, as we learn, Derek Evans is on trial for Tommy's disappearance (The Lost Child, 202) and Ben is about to start his studies at the university. In one of the final scenes, the novel depicts a meeting between Ben and Monica's father, who late in life has become ready to acknowledge his grandson's existence. The man who once shunned contact with his daughter, Ben, and Tommy now longs for connection with the boy who is his only living relative. Ben, however, feels that he has "nothing" to say to him (The Lost Child, 208). The two talk for some time and Ben accepts a check for a small sum offered by the grandfather; this gesture, coupled with a few indifferent words about Ben's plans for the future, fills the old man with hope that "[h]e'll just have to be patient and wait for the lad to contact him" (The Lost Child, 209). The reader, however, may sense that Ben has already made his decision. Namely, he will turn his back on the past, choose his own path, and go his own way. It seems, therefore, that Ben truly stands a chance of being successful in this hostile world depicted by Phillips; similarly to Wuthering Heights, the novel's final message lies in the balance (Eagleton 2005 [1975]: 117). In arriving at this conclusion, however, Phillips seems far more despondent than Emily Brontë and his reinterpretation of the motif does not fill one with hope. In other words, the tragic story of the Lintons and the Earnshaws woven as much out of unhappy love and jealousy as of race, class, and social injustice reverberates in the stories of Monica, Tommy, 
and Ben. One may even argue that some aspects of the experience shown in Wuthering Heights prove erringly contemporary, for example, the fact that those who prosper in the society cannot be too passionate, too sensitive, or too weak. They also need to be versatile in the rules of social economy and amass enough cultural and material capital whenever there is time and opportunity. Only in this way can they secure their position in the world. Those who do not play by the rules, for whatever reason it may be so, are social outcasts. In such a world, one may worryingly note, there is no room for Heathcliff(s). However, in order to fully understand Phillips's take on the Brontë's novel, one needs to delve a bit deeper into the connection he crafts between Tommy and Heathcliff.

In a rare moment of melancholy, which reminds one of the scene in which Catherine was calling for Heathcliff across time and space, Ben stops his car to cast a look at the moors. "I stopped by the side of the road and stared at the depressing landscape. ... I shouted. Tommy! (The Lost Child, 189). Then, "I could feel the moors closing in on me, and for the first time in ages I began to feel close to my brother" (The Lost Child, 189), he says. The story of Tommy then finds its direct connection with Heathcliff, but it does not mean that Tommy is Heathcliff per se. The original Heathcliff is a fantasy, an embodiment of unfulfilled passions, born from the vivid imagination of the Brontë sisters, who, as Phillips implies, might have dreamt of freedom outside the stiff constraints of society. At one point, Phillips invites us into the Brontë household to show the touching contrast between fiction and reality. He shows Charlotte and Emily taking care of their inept father and drunken brother, but secretly dreaming of all their lost loves and possibilities. He makes it clear that the Brontës lived on limited resources and therefore had limited influence on the shape of their own lives. Patrick Brunty's transformation into Patrick Brontë, Phillips writes, "fooled no one, and his attempts to scour the Irish brogue from his tongue and his halfhearted endeavour to dress above his station provoked ill-supressed laughter" (The Lost Child, 99). In a hopeless attempt to win a better social position, the father invested most of his money in his only son, for whom he had high hopes. Unlike his sisters, Branwell could "study art with the finest instructors in the kingdom". Instead, he spent his time "gratifying himself in the taverns" (The Lost Child, 107) and died destitute, surrounded by the loving care of his sisters. Until the very end, the sisters tried to convince themselves that Branwell was a tragic hero who "deserved to be loved and protected, but it was the wickedness of the world that corrupted him" (The Lost Child, 111; italic in the original) and to suppress the regret they must have felt about wasted resources and their own wasted potential. Thus, when Emily "found herself dreaming of the boy who came from the moors" and "turned over and curled up in her mind and begun to search for the boy" (The Lost Child, 105), she found her own unfulfilled dreams of social progress, love and freedom. 
Hence, there manifests itself the unbridgeable gap between what was possible for Heathcliff to achieve, namely to go from a servant to a gentleman, and what was possible for the Brontë sisters, for Monica, Ben, and Tommy. In other words, Phillips deromanticises Heathcliff and, along with him, debunks the myth of the exceptional individual who can achieve whatever he or she wishes for without any help from society. Thus, he impresses on his readers a more collaborative way of thinking where people need help and protection from the community in order to prosper. The tragic stories of Monica and Tommy lack a lofty tone and are closer in their aesthetics to social realism rather than to Shakespearian tragedies. Monica is just a single mother who was not offered a chance to go back to the university, and Tommy a little boy who was too weak to fight against the obstacles that faced him. Vulnerable and exposed as they were, they simply perished on the streets of Leeds and London, failed by the society, the state and its institutions. The novel, then, is a calling for a more responsible and sensitive society that would recognise its own failures and, hopefully, treat them as a lesson for the future. Though one may argue that Phillips's call is idealist and utopian, it is also widely relatable and timely. As Neil Lazarus argues, the poignant experience that permeates the texts from various parts of the globe is that of industrial and post-industrial capitalism. It does not mean that the experience of modernity in every part of the globe is identical, but only "that there is no necessary contradiction between the ideas of the 'universal' and the 'local' or the "national" as we live in the world of "local universalisms", where the experience of capitalism redefined our local communities, landscapes, or even the consumption and production of knowledge, across the globe (Lazarus 2011: 134). Therefore, the present crisis of capitalism is a local as well as universal experience. Unlike many a previous precarious moment in the history of capitalism, however, the present crisis has a systemic character; it cannot be easily alleviated by the mechanisms already in place and requires a redefinition of the system at its core, including the process of the accumulation and redistribution of goods as well as challenging certain myths and ideas on which the system was built (Robinson 2014: 62). One may argue that such claims prove to be infinitely more powerful once shown through individual stories and personal literary narratives. Hence, there is no exaggeration in the claim that we need writers like Caryl Phillips who are ready to actively take part in serious debates on the condition of the world we live in, and the shape of the world we want our children to live in. 


\section{REFERENCES}

\section{PRIMARY SOURCES}

Brontë, Emily. 1992 [1847]. Wuthering Heights. London: Wordsworth's Classics. Phillips, Caryl. 2015. The Lost Child. London: Oneworld Publications.

\section{SECONDARY SOURCES}

Akerlof, George A. \& Rachel E. Kranton. 2010. Identity economics: How our identities shape our work, wages, and well-being. Princeton, NJ: Princeton University Press.

Badger, Emily. 2015. Black poverty differs from white poverty. The Washington Post. https://www.washingtonpost.com/news/wonk/wp/2015/08/12/black-poverty-differsfrom-white-poverty/?noredirect $=$ on\&utm_term $=.7609 \mathrm{de} 4 \mathrm{~d} 062 \mathrm{~d}$ (accessed on 3 May 2018).

Baucom, Ian. 2005. Specters of the Atlantic: Finance capital, slavery, and the philosophy of history. New York, NY: Duke University Press.

Bauman, Zygmunt. 2007. Liquid times: Living in the age of uncertainty. Cambridge: Polity.

Buonnano, Giovanna. 2017. Exploring literary voices in The Lost Child. Commonwealth Essays and Studies 40(1). 95-104.

Dorling, Danny. 2015. Injustice: Why social inequality still persists. Chicago, IL: Policy Press.

Eagleton, Terry. 2005 [1975]. Myths of power: A Marxist study of the Brontës. London: Palgrave MacMillan.

Gilroy, Paul. 1993. The Black Atlantic. Verso: London.

Heuman, Gad. 2014 [2006]. The Caribbean: A brief history. London: Bloomsbury.

Jütte, Robert. 1994. Poverty and deviance in Early Modern Europe. Cambridge: Cambridge University Press.

Kennedy, Melissa. 2017. Narratives of inequality: Postcolonial literary economics. London: Palgrave MacMillan.

Lazarus, Neil. 2011. Cosmopolitanism and the specificity of the local in world literature. Journal of Commonwealth Literature 46(1). 119-137. DOI: 10.1177/0021989410396037

Ledent, Bénédicte. 1996. Is counter-discursive criticism obsolescent? Intertextuality in Caryl Phillips's Higher Ground. In Hena Maes-Jelinek, Gordon Collier \& Geoffrey V. Davis (eds.), A talent(ed) digger: Creations, cameos, and essays in honour of Anna Rutherford, 301-308. Amsterdam: Rodopi.

Loomba, Ania. 2005. Colonialism/Postcolonialism. London: Routledge.

Nasta, Susheila (ed.). 2000. Reading the 'new' literatures in a postcolonial era. Cambridge: D.S. Brewer.

Ramsey-Kurz, Helga \& Melissa Kennedy (eds). 2017. Uncommon wealths in postcolonial fiction. Leiden: Brill.

Robinson, William I. 2014. Global capitalism and the crisis of humanity. Cambridge: Cambridge University Press. DOI: 10.1017/CBO9781107590250

Said, Edward. 1993. Culture and imperialism. London: Vintage.

Schatteman, Renée T. 2009. Introduction. In Renée T. Schatteman (ed.), Conversations with Caryl Phillips, ix-xix. Jackson, MS: The University Press of Mississippi.

Sedláček, Tomáš. 2011. Economics of good and evil: The quest for economic meaning from Gilgamesh to Wall Street. Oxford: Oxford University Press. 
Smith, Christian \& Katherine Sorrell. 2014. On social solidarity. In Vincent Jeffries (ed.), The Palgrave handbook of altruism, morality, and social solidarity, 219-247. London: Palgrave MacMillan. DOI: 10.1057/9781137391865 10

Williams, Eric. 1944. Capitalism and slavery. Chapel Hill, NC: The University of North Carolina Press. 